\title{
The hypothalamus and the regulation of energy homeostasis: lifting the lid on a black box
}

\author{
Gareth Williams*, Joanne A. Harrold and David J. Cutler \\ Diabetes and Endocrinology Research Group, Department of Medicine, The University of Liverpool, Liverpool L69 $3 G A$, UK
}

\begin{abstract}
The hypothalamus is the focus of many peripheral signals and neural pathways that control energy homeostasis and body weight. Emphasis has moved away from anatomical concepts of 'feeding' and 'satiety' centres to the specific neurotransmitters that modulate feeding behaviour and energy expenditure. We have chosen three examples to illustrate the physiological roles of hypothalamic neurotransmitters and their potential as targets for the development of new drugs to treat obesity and other nutritional disorders. Neuropeptide Y (NPY) is expressed by neurones of the hypothalamic arcuate nucleus (ARC) that project to important appetite-regulating nuclei, including the paraventricular nucleus (PVN). NPY injected into the PVN is the most potent central appetite stimulant known, and also inhibits thermogenesis; repeated administration rapidly induces obesity. The ARC NPY neurones are stimulated by starvation, probably mediated by falls in circulating leptin and insulin (which both inhibit these neurones), and contribute to the increased hunger in this and other conditions of energy deficit. They therefore act homeostatically to correct negative energy balance. ARC NPY neurones also mediate hyperphagia and obesity in the $o b / o b$ and $d b / d b$ mice and $f a / f a$ rat, in which leptin inhibition is lost through mutations affecting leptin or its receptor. Antagonists of the Y5 receptor (currently thought to be the NPY 'feeding' receptor) have anti-obesity effects. Melanocortin-4 receptors (MC4-R) are expressed in various hypothalamic regions, including the ventromedial nucleus and ARC. Activation of MC4-R by agonists such as $\alpha$-melanocyte-stimulating hormone (a cleavage product of pro-opiomelanocortin which is expressed in ARC neurones) inhibits feeding and causes weight loss. Conversely, MC4-R antagonists such as 'agouti' protein and agouti gene-related peptide (AGRP) stimulate feeding and cause obesity. Ectopic expression of agouti in the hypothalamus leads to obesity in the $\mathrm{A}^{\mathrm{VY}}$ mouse, while AGRP is co-expressed by NPY neurones in the ARC. Synthetic MC4-R agonists may ultimately find use as anti-obesity drugs in human subjects Orexins-A and -B, derived from prepro-orexin, are expressed in specific neurones of the lateral hypothalamic area (LHA). Orexin-A injected centrally stimulates eating and prepro-orexin mRNA is up regulated by fasting and hypoglycaemia. The LHA is important in receiving sensory signals from the gut and liver, and in sensing glucose, and orexin neurones may be involved in stimulating feeding in response to falls in plasma glucose.
\end{abstract}

Hypothalamus: Obesity: Neuropeptide Y: Melanocortins: Orexins: Leptin

The regulation of energy homeostasis, and the maintenance of body weight and fat mass optimal to the animal's needs, is an extremely complicated process. Its success depends on the brain being able to read, interpret and integrate a wide range of signals that describe the animal's nutritional state and its immediate environment, and to make appropriate adjustments in food intake, energy expenditure and metabolism as a result of the information received. The fact that body weight and fat mass are so accurately regulated in mammals (to within $0 \cdot 5-1 \%$ under reasonably steady-state conditions) highlights the precision with which the brain responds to nutritional signals and its capacity to compensate for the disturbances that follow events such as feeding, exercise or alterations in ambient temperature.

Responsibility for controlling energy homeostasis is shared between several brain regions, as is evidenced in man by the effects on food intake of factors such as the sight and smell of food, the number and conviviality of eating 
companions, and the size and ultimate resting place of the restaurant bill (Hill \& Peters, 1998; Woods et al. 1998). The brain regions involved span the range of 'higher' and 'lower' centres (from cortex to brainstem), but most interest has settled on the hypothalamus.

During the last couple of decades, our factual knowledge of the hypothalamus has expanded dramatically; our understanding of how it actually controls energy balance has also increased, but at a less impressive rate. Descriptions of the hypothalamus have evolved from the purely structural (nuclei, 'areas' and fibre tracts) through the neurochemical (characterizing the distributions of neuropeptides and transmitters and their receptors), and are now beginning to reach the stage of functional understanding, defining exactly which neuronal populations respond to specific nutritional and related signals, and how they pass on that information.

The present review is inevitably highly selective, as about fifty neurochemical markers have been identified so far in hypothalamic neurones, and many are suggested to be involved in controlling feeding and energy balance (an incomplete list is given in Table 1). We have confined ourselves to considering just three of these, ie. neuropeptide $\mathrm{Y}$ (NPY), the melanocortins (MC) and the recentlydiscovered peptides called orexins (also known as 'hypocretins').

\section{Basic anatomy of the hypothalamus}

Conventional histological techniques readily reveal nuclei as clusters of neurones within the hypothalamus, and classical (but crude) experiments employing lesions or electrical stimulation have been interpreted as showing that some of these nuclei act as discrete 'feeding' and 'satiety' centres. The situation is much more complex than these approaches would suggest, although some functional aspects are now emerging that parallel earlier conclusions; for example, the lateral hypothalamus, which was thought to contain the 'feeding' centre, is now known to be extremely sensitive to the appetite-stimulating action of NPY, and is

Table 1. Some hypothalamic neurotransmitters and their receptors implicated in the control of feeding

\begin{tabular}{|c|c|}
\hline Stimulate feeding & Inhibit feeding \\
\hline Neuropeptide Y, via Y5 receptor & $\begin{array}{l}\text { Glucagon-like peptide-1 } \\
\qquad \text { (GLP-1), via GLP-1 receptor }\end{array}$ \\
\hline $\begin{array}{l}\text { Melanin-concentrating hormone, } \\
\text { via SLC-1 }\end{array}$ & $\begin{array}{l}\alpha \text {-Melanocyte-stimulating } \\
\text { hormone, via MC4-R }\end{array}$ \\
\hline $\begin{array}{l}\text { Orexin-A, via orexin-1 or }-2 \\
\text { receptors }\end{array}$ & $\begin{array}{l}\text { Cholecystokinin }(\mathrm{CCK}) \text { via } \\
\mathrm{CCK}_{\mathrm{A}} \text { and } \mathrm{CCK}_{\mathrm{B}} \text { receptors }\end{array}$ \\
\hline Galanin, via galanin-1 receptor & $\begin{array}{l}\text { Cocaine- and amphetamine- } \\
\text { regulated transcript, via an } \\
\text { unknown receptor }\end{array}$ \\
\hline $\begin{array}{l}\text { Agouti gene-related protein, via } \\
\text { melanocortin-4 receptor (MC4-R) }\end{array}$ & $\begin{array}{l}\text { Corticotrophin-releasing factor } \\
\text { (CRF), via CRF receptors } 1\end{array}$ \\
\hline $\begin{array}{l}\text { Glutamate, via N-methyl-D-aspartate } \\
\text { receptor }\end{array}$ & and 2 \\
\hline \multicolumn{2}{|l|}{$\begin{array}{l}\gamma \text {-Aminobutyric acid (GABA), via } \\
\text { GABA }_{A} \text { receptor }\end{array}$} \\
\hline Dynorphin, via $\kappa$ opioid receptor & \\
\hline
\end{tabular}

SLC-1, somatostatin-like cloned receptor-1. also the site of origin of neurones expressing other orexigenic peptides, notably melanin-concentrating hormone $(\mathrm{MCH})$ and the orexins or hypocretins.

It is still useful to refer to the classical neuroanatomical structures of the hypothalamus (Fig. 1). The main regions relevant to the present review are:

the arcuate nucleus (ARC), enclosing the base of the third ventricle and lying immediately above the median eminence. The ARC - median eminence area is one of the 'circumventricular' organs in which the blood-brain barrier is specially modified and allows the entry of circulating peptides and proteins, including insulin and leptin, both of which are considered to be signals of fat mass (Schwartz et al. 1992; Friedman \& Halaas, 1998). The ARC contains populations of neurones that express NPY (together with agouti gene-related peptide, AGRP) and the MC precursor, pro-opiomelanocortin (POMC);

the paraventricular nucleus (PVN) and ventromedial nucleus of the hypothalamus (VMH) to distinguish it from the thalamic ventromedial nucleus). The PVN is a site where numerous neuronal pathways implicated in energy balance converge, including major projections from the NPY neurones of the ARC and others containing orexins, the POMC derivative $\alpha$-melanocyte-stimulating hormone $(\alpha-\mathrm{MSH})$ and the appetite-stimulating peptide galanin. Lesions of either the ventromedial hypothalamic nucleus or the PVN produce impressive syndromes of hyperphagia and obesity, but it is not entirely clear whether these syndromes are due to damage to neurones themselves or to fibres passing through these regions. Recently, the ventromedial hypothalamic nucleus has been identified as a key target for leptin, which acts on the hypothalamus to inhibit feeding, stimulate energy expenditure and cause weight loss (Satoh et al. 1997);

the dorsomedial hypothalamic nucleus (DMH), which has extensive connections with other medial hypothalamic nuclei and the lateral hypothalamus, and is thought to serve an integrative role in processing information from neuronal populations in these sites (Elmquist et al. 1998);



Fig. 1. Basic anatomy of the rat hypothalamus, in longitudinal section ( $A$; caudal is to the right), and in schematized frontal section $(B)$, to show the main regions implicated in energy homeostasis. ARC, arcuate nucleus; DMH, dorsomedial nucleus; LHA, lateral hypothalamic area; pit, pituitary; PVN, paraventricular nucleus; $\mathrm{VMH}$, ventromedial nucleus. 
the vaguely-defined lateral hypothalamic area (LHA) which has a lower density of cell bodies than the obvious nuclei but includes neurones expressing $\mathrm{MCH}$ and the orexins. It also contains numerous fibre systems projecting to and from the medial hypothalamus, brainstem structures that are concerned with various visceral functions and with relaying taste and gastric distension (nucleus of the solitary tract and parabrachial nucleus), and the locus coeruleus, concerned with arousal and the sleep-wake cycle (Bernardis \& Bellinger, 1996). The LHA was the classical 'feeding' centre; interestingly, as well as encompassing neurones and terminals containing orexigenic peptides, it also contains glucose-sensitive neurones that are stimulated by hypoglycaemia (mainly indirectly, by pathways ascending from the brainstem), and it is crucial in mediating the marked hyperphagia which is normally induced by hypoglycaemia (Bernardis \& Bellinger, 1996). The perifornical part of the LHA, surrounding the longitudinal fibre bundle of the fornix, contains a high density of NPY receptors, notably the 'Y5' type thought to be the NPY 'feeding' receptor, and like the adjacent PVN, is highly sensitive to the hyperphagic effect of locally-injected NPY.

\section{Neuropeptide $\mathbf{Y}$}

NPY contains thirty-six amino acid residues, including a tyrosine at each end (hence ' $Y$ ', the code for Tyr). It has the hairpin shape characteristic of the pancreatic polypeptide family, to which it belongs.

NPY is one of the most abundant known neuropeptides in the nervous system of mammals, and is expressed at high levels in several central nervous system (CNS) regions, including the hypothalamus. Under normal conditions NPY-expressing neurones in the rodent hypothalamus are essentially confined to the ARC, where they lie close to the third ventricle in the medial part of the nucleus; these neurones send dense projections to other hypothalamic nuclei, particularly the PVN, DMH and LHA (Chronwall, 1985; Morris, 1989); (Fig. 2). The hypothalamus also receives NPY inputs that originate from outside its boundaries, notably cell groups in the medulla that express catecholamines as well as NPY. Under exceptional circumstances, such as 'knockout' of the MC-4 receptor (MC4-R) described later (pp 389-390) (Kesterson et al. 1997) and also apparently in diet-induced obesity (Guan et al. 1998), NPY expression becomes obvious in cell bodies of the DMH. Most of the work done on the role of NPY in energy homeostasis probably reflects mainly the influence of the ARC NPY neurones; the importance of the ascending projection from the medullary NPY and catecholamine cell groups, and of the 'ectopic' NPY expression in the $\mathrm{DMH}$, remains uncertain.

The ARC NPY neurones are strategically situated to integrate a variety of nutritional and neural signals, and to interact with and influence other neuronal systems (Dryden et al. 1994). A subpopulation of the ARC NPY neurones expresses the 'long' isoform of the leptin receptor (known as $\mathrm{OBRb}$; the fully functional form with intact intracellular signalling domains) and these cells appear to respond specifically under conditions in which circulating leptin levels are altered (Baskin et al. 1999). As mentioned earlier, this part of the hypothalamus is readily and rapidly accessible to circulating leptin (Banks et al. 1996), and there is firm evidence that leptin inhibits NPY expression and decreases NPY levels in the ARC (Stephens et al. 1995; Wang et al. 1997). The NPY neurones are therefore potential hypothalamic targets for leptin, and inhibition of the synthesis (and presumably release) of the powerfully orexigenic NPY seems likely to explain, at least partly, the ability of leptin to induce hypophagia and weight loss. Insulin has the same central actions as leptin on energy balance and, before the discovery of leptin, was attributed an important role as a signal that reflects fat mass (Schwartz et al. 1992; Dryden et al. 1994). Insulin receptors are expressed in the mediobasal hypothalamus, and especially the median eminence, and insulin has been shown to inhibit NPY synthesis and its secretion in the PVN; however, it is not clear whether insulin receptors are actually carried by the NPY neurones or by neurones that impinge on them (Schwartz et al. 1992; Dryden et al. 2000).

In addition to these circulating factors, the NPY neurones have extensive neural routes of communication with other hypothalamic regions and specific neuronal populations involved in energy homeostasis (Dryden et al. 2000; Fig. 2). These routes of communication include reciprocal connections with systems that inhibit feeding (e.g. corticotrophin-releasing factor neurones in the PVN, POMC neurones in the ARC and serotonergic neurones in the raphe nuclei of the midbrain), and other systems that stimulate eating (e.g. the $\mathrm{MCH}$ and orexin cell populations of the LHA). Another intriguing twist in the story, which underlines the complexity of the controls placed over feeding behaviour, is the recent demonstration that most of the NPY neurones of the ARC also express AGRP; this factor acts as an endogenous antagonist at the MC-4 receptor (MC4-R) that mediates the appetite-suppressing action of $\alpha-\mathrm{MSH}$ released from POMC neurones (see p. 389).

There is, therefore, much potential for interaction at several levels between NPY and other neuronal systems; the balance between these systems, and the extent and nature of compensatory changes that might follow changes in the activity of a single system, presumably determines overall feeding behaviour patterns. Such factors will also determine, amongst other things, the ability of the animal to survive starvation and the therapeutic efficacy of drugs that target the NPY 'feeding' receptor with the aim of treating obesity and other human nutritional disorders.

\section{Neuropeptide $Y$ and energy homeostasis}

NPY is a powerful stimulator of feeding when injected into the PVN and perifornical LHA of rodents; indeed, it and its C-terminal derivatives (e.g. $\mathrm{NPY}_{3-36}$ ) are amongst the most potent orexigenic substances yet identified (Kalra et al. 1991a; Flynn et al. 1999). Interestingly, hyperphagia is accompanied by inhibition of the sympathetic outflow to brown adipose tissue and other thermogenic tissues, leading to a fall in energy expenditure and a net shift towards positive energy balance (Egawa et al. 1991). Obesity results if central NPY administration is continued for a few days, and this process is accompanied by insulin resistance in 


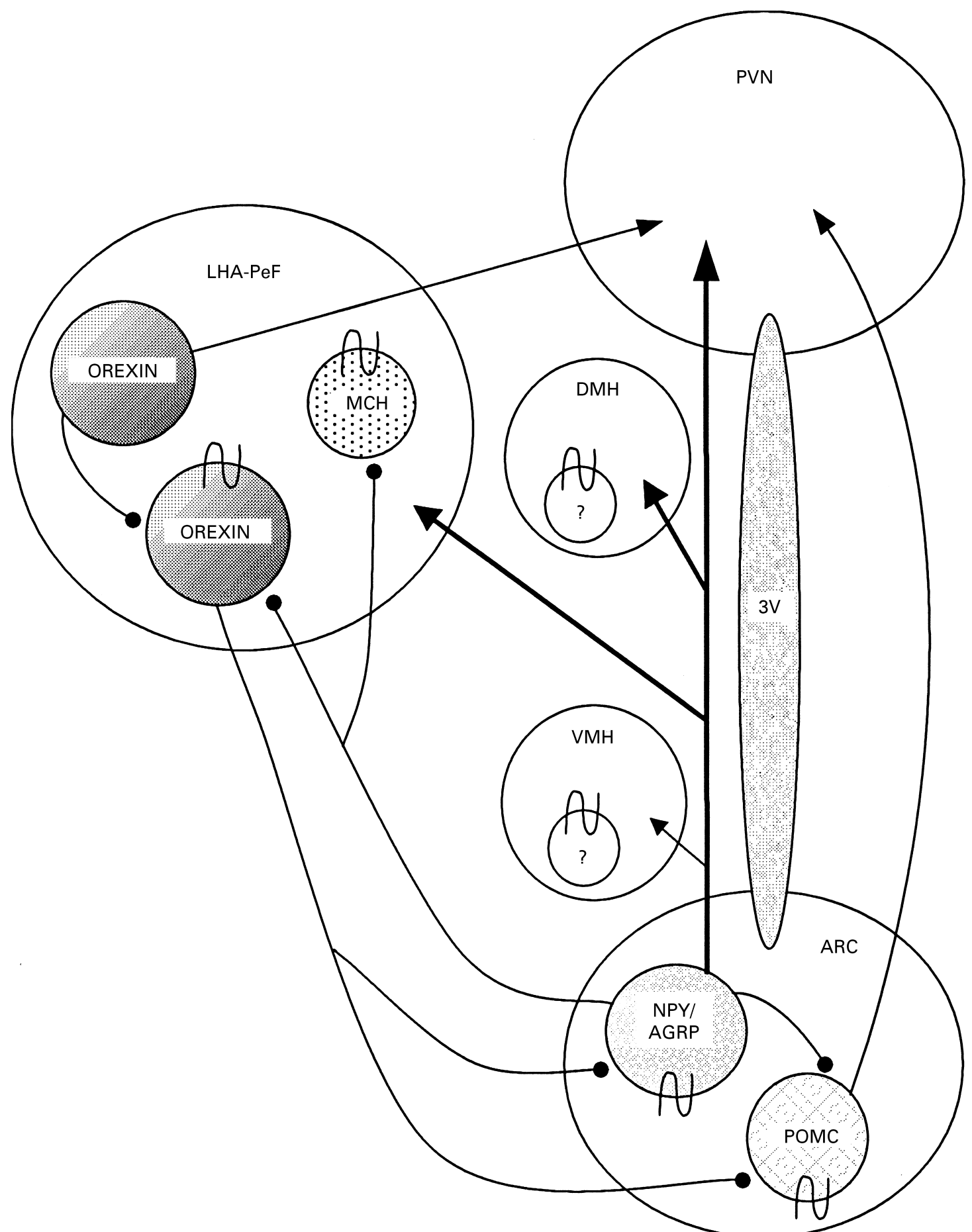

Fig. 2. Anatomical-neuropeptidergic interactions in the hypothalamus. Neuropeptide Y (NPY) and agouti gene-related protein (AGRP) neurones in the arcuate nucleus (ARC) send dense projections to orexin and melanin-concentrating hormone ( $\mathrm{MCH}$ ) cells in the lateral hypothalamicperifornical area (LHA-PeF), ARC pro-opiomelanocortin (POMC) cells and chemically unidentified neurones in the paraventricular (PVN), dorsomedial (DMH) and ventromedial (VMH) nuclei. LHA orexin neurones innervate ARC NPY and AGRP and POMC cells, in addition to other LHA orexin neurones. ARC POMC cells project heavily to the PVN, where numerous feeding-related pathways converge. Many of the chemical targets described earlier also express functional leptin receptors (几). 3V, third ventricle.

muscle (Vettor et al. 1994). The resulting syndrome mimics, although to a lesser degree, the energetic and metabolic features of the well-known rodent genetic models of obesity, notably the $o b / o b$ mouse and fa/fa Zucker rat. As discussed later (p. 389), both these models show good evidence that the ARC NPY neurones are overactive (a predictable consequence of the loss of the inhibitory leptin signal in these mutants), and this overactivity is probably partly responsible for their hyperphagia, reduced energy expenditure and excessive fat gain. 
Six NPY receptors have been cloned so far, of which one is truncated and inactive in rat and man (Inui, 1999). The balance of evidence favours the 'Y5' type as the one that mediates the hyperphagic and obesity-promoting effects of NPY. The Y5 receptor is expressed at relatively high levels in the LHA, close to the site where NPY acts most potently to simulate feeding (Gerald et al. 1996). NPY receptor density in this area is decreased during starvation, which may be explained by down regulation of these receptors following increased local availability of NPY (Widdowson et al. 1997); as discussed later (p. 389), NPY release is known to be enhanced during food deprivation (Kalra et al. 1991b). Overall, NPY receptors (putatively Y5) in this area appear well placed to participate in mediating the increased hunger and food-seeking behaviour of the food-deprived animal.

The pharmacology of the Y5 receptor matches closely the potency of the orexigenic effects of a range of NPY derivatives (Gerald et al. 1996), and it has been shown that reducing Y5 receptor availability, either by using antisense oligodeoxynucleotides targeted against Y5 mRNA (Schaffauser et al. 1997) or with a synthetic high-affinity Y5 antagonist (Criscione et al. 1998), can decrease spontaneous feeding and the hyperphagia induced by central injection of exogenous NPY. Interestingly, however, the Y5 'knockout' mouse shows no reductions in feeding or weight (Erickson et al. 1996a). This finding is difficult to reconcile with the other convincing evidence that implicates the 'Y5' type as the 'feeding' receptor, but may reflect the general difficulties of applying the 'knockout' approach to systems such as energy homeostasis, which are regulated by several systems that interact to a considerable degree.

Further evidence that NPY is involved in driving feeding under at least some conditions derives from the findings of increased hypothalamic NPY neuronal activity in a range of conditions characterized by weight loss and increased hunger. In these circumstances several groups have reported increased NPY expression, raised NPY peptide levels in the ARC and PVN in particular, and elevated NPY secretion in the PVN (measured directly in conscious animals using the stereotactic 'push-pull' sampling technique; Dryden et al. 1994, 2000). These states include food restriction and fasting, insulin-deficient diabetes and lactation, especially when mild food restriction is superimposed (Smith, 1993; Pickavance et al. 1996; Dryden et al. 2000). Under these conditions, plasma leptin levels fall in parallel with the decline in body fat mass, and the enhanced NPY neuronal activity may be due to loss of inhibition by leptin. Concomitant falls in insulin, which also inhibits ARC NPY neuronal activity (Schwartz et al. 1992; Dryden et al. 1994), may also contribute.

Overall, these observations suggest that the ARC NPY neurones lie at the point of impact of important circulating nutritional signals, and that they effectively sense depletion of body fat; as the effects of NPY tend to restore positive energy balance, it has been suggested that these neurones serve a homeostatic function in defending body energy stores. At first sight, this argument is challenged by the observation that the NPY 'knockout' mouse has normal food intake and body weight (Erickson et al. 1996a). However, in our view, the balance of evidence favours an active role of NPY in driving feeding under conditions of negative energy balance, and we would once again express our reservations about the validity of the 'knockout' approach to test hypotheses about physiological control systems that display much 'redundancy' and a large capacity for compensatory adaptation. Perhaps reassuringly, it has been shown recently that hyperphagia in insulindeficient diabetic mice is attenuated by knockout of the NPY gene (Sindelar et al. 1999).

\section{Neuropeptide $Y$ and obesity}

ARC NPY neuronal activity is increased in the $o b / o b$ mouse and the $f a / f a$ Zucker rat, similarly to the changes seen in states of energy deficits in which leptin levels fall and fat mass is depleted (Sanacora et al. 1990; McKibbin et al. 1991; Wilding et al. 1993). NPY may partly drive the hyperphagia that contributes to obesity in these models, as food intake falls with administration of a potent Y5 antagonist (Criscione et al. 1998), and in ob/ob mice that also have the NPY gene knocked out (Erickson et al. 1996b). In these mutants NPY overactivity is clearly inappropriate to the nutritional needs of the animal, and presumably arises through interruption of the normal inhibitory influence of leptin, as a result of the $o b$ mutation (which abolishes the production of biologically-active leptin) and the fa mutation (which affects the leptin receptor and reduces the animals' sensitivity to leptin; Phillips et al. 1996; Dryden et al. 1999).

By contrast, dietary obesity induced by voluntary overeating of a highly-palatable diet is not accompanied by obvious increases in the activity of the ARC NPY neurones; indeed, there is some evidence that aspects of their activity are inhibited, perhaps suggesting an attempt to restrain overeating of palatable food (Wilding et al. 1992; Widdowson et al. 1997). On the other hand, in mice at least, dietary obesity seems to induce the emergence of 'ectopic' NPY expression in the DMH (Guan et al. 1998). The possible contribution of NPY to dietary obesity, and to overeating which is driven by the hedonic attractions of palatable food rather than the physiological consequences of energy deprivation, remains to be elucidated.

\section{Melanocortins and the melanocortin-4 receptor}

The hypothalamic MC neuronal system is now strongly implicated in the regulation of food intake and body weight. These neurones produce peptides, all derived from the common precursor, POMC, of which $\alpha-\mathrm{MSH}$ is apparently the most relevant to feeding. Most POMC neurones lie within the ARC, and discrete $\alpha$-MSH-containing pathways project from the ARC to many brain regions, particularly elsewhere in the hypothalamus. Three melanocortin receptors (MC-R; MC3-R, MC4-R and MC5-R) are found in the brain, and both MC3-R and MC4-R are expressed in various hypothalamic regions (Roselli-Rehfuss et al. 1993; Mountjoy et al. 1994) including the ventromedial hypothalamic nucleus, DMH and ARC-median eminence (Harrold et al. 1999a).

$\alpha$-MSH has been assumed to be the endogenous ligand at all CNS MC-R, but its physiological function within the CNS remained mysterious until a 131 amino acid protein, 
termed agouti, was found to antagonize the action of $\alpha$-MSH at these receptors ( $\mathrm{Lu}$ et al. 1994). This discovery was prompted by observations of the obese yellow $\left(\mathrm{A}^{\mathrm{VY}}\right)$ mouse, a long-recognized rodent model of obesity that is inherited as an autosomal dominant trait. Here, a mutation that affects the promoter region of the agouti gene leads to ectopic expression of agouti (expression is usually restricted to the hair follicles) in sites that include the hypothalamus. In hair follicles agouti blocks $\alpha-\mathrm{MSH}$ action at the MC1-R, preventing the normal production of black melanin pigment and thus turning the hair pale (yellow in mice, tan in Alsatian dogs, ginger in man). Antagonism at MC-R in the hypothalamus leads to hyperphagia, reduced energy expenditure and ultimately obesity. Thus, it was suggested that $\alpha$-MSH is tonically released within the hypothalamus and functions to limit food intake and body mass.

Recent data firmly place MC4-R in a central role in this regulatory pathway. Generation of an MC4-R 'knockout' mouse produced a syndrome of obesity very similar to that demonstrated by the $\mathrm{A}^{\mathrm{VY}}$ mouse (Huszar et al. 1997). Additionally, agouti peptide was shown to act as a highly specific functional antagonist at MC4-R, with over 100-fold greater selectivity as compared with its activity at MC3-R (Lu et al. 1994; Fan et al. 1997); however, subsequently, this degree of selectivity has been questioned by Kiefer et al. (1997), who reported a similar affinity at MC3-R and MC4-R. However, administration of the potent $\alpha-\mathrm{MSH}$ analogue, MT-II, reduces food intake, while injection of the agouti mimetic, SHU9119, stimulates feeding; both these peptides demonstrate at least 10-fold higher selectivity for MC4-R over MC3-R (Fan et al. 1997). Recently, an even more potent and selective MC4-R antagonist (HS014) has been shown to induce sustained hyperphagia and obesity (Schioth et al. 1999).

Leptin appears to stimulate the MC pathway, consistent with the fact that both factors inhibit feeding and promote weight loss, and it has been proposed that the MC system mediates some of the central actions of leptin in the brain. Leptin receptor mRNA is concentrated within the $\mathrm{ARC}$, and approximately $30 \%$ of the POMC-expressing neurones here also carry the long isoform of the receptor (OBRb; Cheung et al. 1997). Pharmacological blockade of MC4-R impairs the ability of leptin to reduce food intake and body weight (Seeley et al. 1997). Also, conditions associated with reduced leptin levels (e.g. fasting) or the absence of functional leptin (the $o b / o b$ mouse) show reduced POMC mRNA levels (Mizuno et al. 1998), while leptin treatment of these animals increases hypothalamic POMC mRNA (Schwartz et al. 1997). Leptin therefore appears to stimulate the POMC neurones; increased POMC expression presumably results in enhanced $\alpha$-MSH production and release, leading to reduced food intake via its interaction with MC4-R.

\section{Modulation of melanocortin receptors: role of agouti gene-related peptide}

A unique feature of the MC system is the presence of the endogenous antagonist, agouti, at the MC-R. Recently, a novel peptide termed AGRP was isolated and cloned, based on its sequence homology to the agouti gene (Ollmann et al.
1997). AGRP also appears to function as a MC-R antagonist, but unlike agouti it is normally expressed in the CNS, although restricted to the ARC. AGRP expression increases markedly in $o b / o b$ and $d b / d b$ mice (Ollmann et al. 1997; Shutter et al. 1997), and transgenic mice with ubiquitous AGRP expression develop an obesity syndrome analogous to those of the $\mathrm{A}^{\mathrm{vy}}$ and MC4-R 'knockout' mice (Ollmann et al. 1997). These results imply a role for AGRP in the normal control of body weight, and suggest that activity of the MC4-R could be influenced by antagonist as well as agonist concentrations. Indeed, AGRP may act to 'fine-tune' MC4-R activity, and thus feeding and energy homeostasis, at least under certain conditions. Consistent with this view is evidence that AGRP is regulated more robustly by changes in metabolic status than is the agonist's precursor, POMC (Haskell-Luevano et al. 1999). Moreover, we recently found marked changes in AGRP levels in dietary-obese and food-restricted rats, but no alterations in $\alpha$-MSH or POMC concentrations (Harrold et al. 1999b). Overall, this information suggests that the activity of the MC system may be regulated by alterations in the antagonist, which may modulate background activation by tonic $\alpha$-MSH release. This situation would be comparable with that operating in the follicle to control hair colour, where the levels of agouti modulate the actions of constitutive $\alpha$-MSH on pigment synthesis in the melanocyte.

Another potentially important regulatory role of the MC system is that it apparently influences the activity of the hypothalamic NPY neurones. It has been demonstrated that obese $\mathrm{A}^{\mathrm{VY}}$ mice have unaltered ARC NPY mRNA levels, but that NPY is expressed at high levels in the unusual site of the DMH (Kesterson et al. 1997). This observation also applies to MC4-R 'knockout' mice, and implies that elevated NPY may mediate (at least partly) obesity in this model, as is the case in some other syndromes, including the $o b / o b$ mouse and fa/fa Zucker rat (Dryden et al. 1999). This information suggests that the MC neurones exert control over the NPY system, but further inspection indicates that the interaction between these two neuronal pathways is more complex than simple hierarchical inhibition by the MC. It has been observed that AGRP mRNA is highly co-localized with NPY mRNA in the ARC (98\% of AGRP-positive neurones were found to co-express NPY), but not with POMC mRNA (Broberger et al. 1998b; Fig. 2). The NPY and AGRP neurones, when activated, could therefore exert a dual effect to promote hyperphagia, involving both the activation of NPY receptors and antagonism of MC4-R by AGRP. Furthermore, antagonism of MC activity may also occur through NPY itself. It has been shown that POMC neurones express the NPY Y1 receptor (Dagerlind et al. 1992; Fuxe et al. 1997) and that they receive input from NPY terminals (Csiffary et al. 1990; Dagerlind et al. 1992). Potentially, therefore, NPY released by ARC neurones could inhibit the MC system directly at the cell body (Jegou et al. 1993) or post-synaptically through the release of AGRP.

A role for the MC system in the control of feeding is unquestionable, but its exact position in the chain of events is currently unclear. The location of leptin receptors on POMC neurones suggests that $\alpha-\mathrm{MSH}$ and MC4-R lie 
downstream of leptin; treatment of rodents with an MC4-R antagonist before leptin administration greatly attenuates the hypophagic effect of leptin (Seeley et al. 1997), indicating that the MC4-R is necessary for this activity. Furthermore, $\mathrm{A}^{\mathrm{VY}}$ mice, in which MC4-R are blocked by agouti, become obese despite dramatically elevated plasma leptin levels (Halaas et al. 1997). Recently, however, the production of a genetic cross between $\mathrm{A}^{\mathrm{VY}}$ and $o b / o b$ mice has challenged the assumption that MC4-R lie downstream of leptin in the cascade of control. Obesity in $\mathrm{A}^{\mathrm{VY}}$ mice was thought to be due entirely to defective POMC signalling, which in turn would be predicted to block the leptin signal; the introduction of the $\mathrm{A}^{\mathrm{VY}}$ mutation on to the $o b / o b$ genetic background should therefore have no further effects on weight gain. However, defective POMC signalling and the absence of leptin signalling appeared to be, at least in part, independent and additive, as the presence of $\mathrm{A}^{\mathrm{VY}}$ increased weight gain to a similar extent in both wild-type and $o b / o b$ (leptin-deficient) backgrounds (Boston et al. 1997).

It is clear that the MC system plays a vital role in the control of feeding behaviour and body weight in rodents. Its relevance to human energy homeostasis has also been confirmed recently with the discovery that severe obesity is very rarely associated with specific mutations that affect the MC system, i.e. abnormalities in the POMC gene (Krude et al. 1998) and a frameshift mutation in MC4-R, the latter being associated with dominantly inherited morbid obesity (Yeo et al. 1998).

\section{Orexins (hypocretins)}

The discovery of the orexins has expanded further the growing ensemble of neurotransmitters implicated in the control of food intake and energy homeostasis. Orexin-A and orexin-B are, respectively, thirty-three and twenty-eight amino acid residue peptides, identified from rat brain extracts that activated a G-protein-coupled 'orphan' receptor, i.e. that had no known ligand (Sakurai et al. 1998). The orexins are derived by proteolytic processing of a common peptide precursor, prepro-orexin, which is structurally identical to a peptide identified independently using directional tag-polymerase chain reaction subtraction and termed prepro-hypocretin (de Lecea et al. 1998). Hypocretin-1 and -2 have sequences in common with orexin-A and -B respectively, but additional amino acid residues were deduced to be present in both hypocretin-1 (six amino acids) and hypocretin-2 (one amino acid). In man, the prepro-orexin gene maps to human chromosome 17q21 (Sakurai et al. 1998, 1999), which interestingly is also described as the locus for several neurodegenerative disorders (Wilhelmsen et al. 1994; Wijker et al. 1996).

In rodent, human and monkey brain, neurones expressing prepro-orexin mRNA, or orexin-A or -B peptide, are restricted to the hypothalamus and localized specifically to the LHA, dorsal perifornical nucleus $(\mathrm{PeF})$ and posterior $\mathrm{DMH}$, within the antero-posterior limits of the median eminence (Sakurai et al. 1998; Chen et al. 1999; Cutler et al. 1999; Date et al. 1999; Nambu et al. 1999). Markers for hypocretins identify a neuronal population with a similar distribution (de Lecea et al. 1998; Peyron et al. 1998), and this population is now known to correspond to the group of
LHA cells discovered several years ago using an antiserum to ovine prolactin, which cross-reacts with prepro-orexin (Risold et al. 1999). Neurones in the LHA-PeF region possess immunoreactivity for $\mathrm{MCH}$, another peptide whose mRNA is up regulated in fasting (Qu et al. 1996). Although it was speculated that orexin and $\mathrm{MCH}$ might be co-expressed in the same neurones, it is now clear that they are localized in adjacent, but non-overlapping cell populations (Broberger et al. 1998a; Elias et al. 1998; Peyron et al. 1998; Håkansson et al. 1999). Outside the CNS orexin mRNA has been found in rat testis (Sakurai et al. 1998), but neither orexin-A nor -B peptide is detectable by specific radioimmunoassay or immunohistochemical techniques at any peripheral site (Cutler et al. 1999; Mondal et al. 1999; Taheri et al. 1999).

Complex interactions between the orexins and other hypothalamic neuronal systems are also emerging, and these interactions may represent other routes through which the orexins may affect energy balance and feeding behaviour (Fig. 2). There are reciprocal synaptic contacts between orexin cells and leptin-receptor-expressing NPY and AGRP neurones and POMC neurones in the ARC (Broberger et al. 1998a, b; Elias et al. 1998; Horvath et al. 1999). Moreover, orexin axons contact other orexin cells that express leptin receptors, suggesting possible autoregulation of orexin function (Horvath et al. 1999).

There are two known receptors for the orexins, which show broad but differential distributions in rat brain (Trivedi et al. 1998). These receptors bind the orexins with high (nanomolar range) affinity; the orexin-1 receptor exhibits a 10- to 20 -fold greater selectivity for orexin-A over orexin-B, while the orexin-2 receptor is not selective for the two peptides (Sakurai et al. 1998). Activation of these receptors in hypothalamic cells leads to a marked increase in intracellular $\mathrm{Ca}$ levels, a post-synaptic effect probably mediated via stimulation of a $\mathrm{G}_{\mathrm{q}} \mathrm{G}$-protein and protein kinase $\mathrm{C}$; regulation of glutamate- or $\gamma$-aminobutyric acidgenerated fast synaptic activity by pre-synaptic orexin receptors has also been demonstrated (van den Pol et al. 1998).

The close relationship between orexin-A fibres and the surface of the cerebral ventricular system (Chen et al. 1999; Cutler et al. 1999) suggests that orexin-A may be released directly into the cerebrospinal fluid, where it could interact with other appetite-regulating factors (e.g. leptin and insulin), or perhaps have a neurohormonal role via volume transmission (Zoli et al. 1998).

\section{Orexins, feeding and energy balance}

The LHA-PeF region is firmly implicated in the central control of feeding behaviour and nutritional homeostasis, and the discrete localization of orexin neurones to this area raised the possibility that the orexins play a role in these processes. Initial experiments in the rat showed that intracerebroventricular injection of orexin-A or -B dramatically stimulated food intake (10-fold at $2 \mathrm{~h}$ ), while a $48 \mathrm{~h}$ period of fasting elevated hypothalamic prepro-orexin mRNA levels (Sakurai et al. 1998). On the basis of these results, the name 'orexin' (from the Greek for 'appetite') was coined for these peptides. 
The appetite-stimulating property of the orexins has been substantiated in the rat, mouse and pig (Dyer et al. 1999), although their orexigenic effects now appear to be less robust than described initially. The characteristic response to orexin-A injected intracerebroventricularly or into the LHA and PeF is an immediate increase in feeding, with a maximal effect (3-fold) less potent than that first reported; this effect is transient, so that total food intake after $6 \mathrm{~h}$ is not increased, and is not reliably concentration-dependent (Edwards et al. 1999; Sweet et al. 1999). The effect of orexin-B on food intake is less consistent than that with orexin-A, and some reports have shown no stimulation, even when it is injected into the LHA or PeF (Lubkin \& Stricker-Krongrad, 1998; Sweet et al. 1999). The stimulatory actions of orexins on feeding may have circadian dependence, as they are effective only during the light phase, when rodents normally eat little (Haynes et al. 1999). However, the activity of the orexin neurones appears not to be under circadian control, as levels of prepro-orexin mRNA or orexin-A peptide remain unchanged between 24.00 hours and 12.00 hours (Mondal et al. 1999).

The speculative role of the orexins as a trigger to induce feeding is strengthened by the finding that fasting up regulates orexin mRNA and may induce release of the orexins into various brain regions (Mondal et al. 1999; see also Taheri et al. 1999). However, evidence is emerging to indicate that the orexins may stimulate feeding under specific circumstances of increased hunger. We (Cai et al. 1999) and others (Griffond et al. 1999) have found that prepro-orexin mRNA is elevated only under conditions of increased appetite when plasma glucose falls and food is absent from the gut, i.e. prolonged fasting or hypoglycaemia when food is witheld. Intriguingly, about $25 \%$ of LHA neurones are glucose sensitive, being inhibited by elevated circulating glucose levels and stimulated by falls in glucose (Bernardis \& Bellinger, 1996). This gluco-sensitive population of LHA cells may include some orexin neurones, as insulin-induced hypoglycaemia stimulates the expression of the neuronal marker Fos in a subset (about one-third) of them (Moriguchi et al. 1999). Alternatively, the increase in feeding induced by the orexins may be related to factors other than changes in glucose levels, as centrally-injected orexin-A increases energy metabolism and vagal nervedependent gastric acid secretion, responses which could subsequently initiate feeding (Lubkin \& Stricker-Krongrad, 1998; Takahashi et al. 1999).

Leptin, an important regulator of both NPY and POMC neurones, may also influence orexin neuronal activity. As mentioned previously, a subset of orexin neurones expresses the leptin receptor (Horvath et al. 1999), but functional evidence of an interaction is less clear. Prepro-orexin mRNA is reduced in leptin signalling-deficient $o b / o b$ and $\mathrm{db} / \mathrm{db}$ mice, and $7 \mathrm{~d}$ leptin treatment decreased orexin-A levels in the rat LHA-PeF; on the other hand, hypothalamic orexin-A content was unchanged in both fasted and overfed rats, and in lean or obese Zucker rats (Beck \& Richy, 1999; Taheri et al 1999; Yamamoto et al. 1999). Moreover, our own studies (Cai et al. 1999) did not show any significant changes in prepro-orexin mRNA levels over a range of conditions in which circulating leptin levels alter dramatically (underfeeding, dietary obesity, insulin-deficient diabetes), or in food restriction with or without leptin treatment that prevented the usual fall in leptin levels.

\section{Other possible functions of orexins}

Neurones in the LHA-PeF region have also been implicated in functions additional to the regulation of energy homeostasis and feeding. The extensive projections of orexin fibres to many brain and spinal cord regions (Peyron et al. 1998; Chen et al. 1999; Cutler et al. 1999; Date et al. 1999; Nambu et al. 1999; van den Pol, 1999) hints at the possible involvement of the orexins in a host of other autonomic, neuroendocrine and behavioural activities (Table 2). The role the orexins may play, if any, in these processes is unclear, but many nuclei rich in orexin fibres express Fos in response to orexin administration (Date et al. 1999; Edwards et al. 1999). Central administration of orexin-A or

Table 2. Selective brain regions which receive a robust innervation of orexin-immunoreactive axons and the potential contribution of the orexins to the function(s) associated with those nuclei (Peyron et al. 1998; Cutler et al. 1999; Date et al. 1999; Nambu et al. 1999; van den Pol, 1999, and references contained therein)

Brain region Function

LHA, PeF, arcuate nucleus, paraventricular nucleus, area postrema, piriform cortex, amygdala, septal nuclei, bed nucleus of the stria terminalis

LHA, PeF, subfornical nucleus, area postrema

Parabrachial nuclei, nucleus of the solitary tract, dorsal motor nucleus of the vagus

LHA, PeF, area postrema, central grey, raphe nuclei, parabrachial nuclei, locus coeruleus, nucleus of the solitary tract, rostral ventrolateral medulla

Thalamic paraventricular nucleus, raphe nuclei, preoptic area, suprachiasmatic nucleus, locus coeruleus, nucleus of the solitary tract, dorsal motor nucleus of the vagus, spinal cord

Spinal cord (laminae $1 / 2$ and 10), locus coeruleus, central grey

LHA, PeF, hippocampus, nucleus accumbens, amygdala, septal nuclei, ventral tegmental area, indusium griseum, raphe nuclei

Locus coeruleus, nucleus of the solitary tract, spinal cord, thalamic paraventricular nucleus, dorsal motor nucleus of the vagus, autonomic part of the paraventricular nucleus

Oflactory bulbs, dorsal endopiriform nucleus, tenia tecta, piriform cortex

LHA, subcoeruleus areas, raphe magnus

Preoptic area, arcuate nucleus, septal nuclei
Feeding and energy balance

Water intake

Regulation of visceral organ function

Cardiovascular and blood pressure control

Sleep-wake cycle and arousal level

Modulation of sensory information

Regulation of emotion and emotional behaviour

Control of autonomic nervous system

Olfaction

Thermoregulation

Reproduction

LHA, lateral hypothalamic area; PeF, perifornical nucleus. 
-B at lower doses than stimulate feeding increases blood pressure, autonomic efferent nerve activity and luteinizing hormone secretion in steroid-treated ovariectomized rats $(\mathrm{Pu}$ et al. 1998; Samson et al. 1999; A. Niijima and K Nagai, unpublished results). There are increases in grooming, burrowing and searching behaviours following intracerebroventricular injection of orexin-A or -B in the rat, suggesting that they may increase vigilance and regulate arousal states (Ida et al. 1999). The potential importance of the orexins in arousal and the sleep-wake cycle has been emphasized by the discoveries that knockout of the mouse orexin gene induces a narcolepsy-like state, and that narcolepsy in dogs is caused by a mutation affecting the orexin-2 receptor (Chemelli et al. 1999; Lin et al. 1999; Siegel, 1999).

\section{Conclusions}

The three neuropeptides which we have selected for the present review illustrate clearly the complexities of the many homeostatic circuits that co-operate to control feeding and energy balance. We can justify these choices now, because these three neuropeptides are amongst the most promising of the hypothalamic factors thought to control feeding behaviour and body weight, at least in rodents. However, we cannot predict how their stature might compare with other hypothalamic neurotransmitters that will undoubtedly be discovered in the future. There is also no guarantee that this information, which originates almost exclusively from rodents, will provide any useful insights into the regulation of human energy balance, or will lead the way to new and effective treatments for obesity and other nutritional disorders in man.

Nonetheless, the ever more rapid acquisition of knowledge will continue to raise new therapeutic targets and, with them, new hopes for novel and effective treatments for obesity and other nutritional disorders in man.

\section{References}

Banks WA, Kastin AJ, Huang W, Jaspan JB \& Maness LM (1996) Leptin enters the brain by a saturable system independent of insulin. Peptides 17, 305-311.

Baskin DG, Breininger JF \& Schwartz MW (1999) Leptin receptor mRNA identifies a subpopulation of neuropeptide $\mathrm{Y}$ neurons activated by fasting in rat hypothalamus. Diabetes $\mathbf{4 8}$, 828-833.

Beck B \& Richy S (1999) Hypothalamic hypocretin/orexin and neuropeptide Y: Divergent interaction with energy depletion and leptin. Biochemical and Biophysical Research Communications 258, 119-122.

Bernardis LL \& Bellinger LL (1996) The lateral hypothalamic area revisited: Ingestion behavior. Neuroscience and Biobehavior Reviews 20, 189-287.

Boston BA, Blaydon KM, Varnerin J \& Cone RD (1997) Independent and additive effects of central POMC and leptin pathways on murine obesity. Science 278, 1641-1644.

Broberger C, de Lecea L, Sutcliffe JG \& Hökfelt T (1998a) Hypocretin/orexin- and melanin-concentrating hormoneexpressing cells form distinct populations in the rodent lateral hypothalamus: Relationship to the neuropeptide $\mathrm{Y}$ and agouti gene-related protein systems. Journal of Comparative Neurology 402, 460-474.
Broberger C, Johansen J, Johansson C, Schalling M \& Hökfelt T (1998b) The neuropeptide Y/agouti gene-related protein (AGRP) brain circuitry in normal, anorectic, and monosodium glutamatetreated mice. Proceedings of the National Academy of Sciences USA 95, 15043-15048.

Cai X, Widdowson PS, Harrold J, Wilson S, Buckingham R, Arch JRS, Tadayyon M, Clapham JC, Wilding J \& Williams G (1999) Hypothalamic orexin expression: Modulation by blood glucose and feeding. Diabetes 48, 2132-2137.

Chemelli RM, Willie JT, Sinton CM, Elmquist JK, Scammell T, Lee C, Richardson JA, Williams SC, Xiong Y, Kisanuki Y, Fitch TE, Nakazato M, Hammer RE, Saper CB \& Yanagisawa M (1999) Narcolepsy in orexin knockout mice: Molecular genetics of sleep regulation. Cell $\mathbf{9 8}, 437-451$.

Chen C-T, Dun SL, Kwok EH, Dun NJ \& Chang J-K (1999) Orexin A-like immunoreactivity in the rat brain. Neuroscience Letters 260, 161-164.

Cheung CC, Clifton DK \& Steiner RA (1997) Proopiomelanocortin neurons are direct targets for leptin in the hypothalamus. Endocrinology 138, 4489-4492.

Chronwall BM (1985) Anatomy and physiology of the neuroendocrine arcuate nucleus. Peptides 6, 1-11.

Criscione L, Rigollier P, Batzl-Hartmann C, Rueger $\mathrm{H}$, Stricker-Krongrad A, Wyss P, Brunner L, Whitebread S, Yamaguchi Y, Gerald C, Heurich RO, Walker MW, Chiesi M, Schilling W, Hofbauer KG \& Levens N (1998) Food intake in free-feeding and energy-deprived lean rats is mediated by the neuropeptide Y5 receptor. Journal of Clinical Investigation 102, 2136-2145.

Csiffary A, Gorcs TJ \& Palkovits M (1990) Neuropeptide Y innervation of ACTH-immunoreactive neurons in the ARC of rats: A correlated light and electron microscopic double immunolabeling study. Brain Research 506, 215-222.

Cutler DJ, Morris R, Sheridhar V, Wattam TAK, Holmes S, Patel S, Arch JRS, Wilson S, Buckingham RE, Evans ML, Leslie RA \& Williams G (1999) Differential distribution of orexin-A and orexin-B immunoreactivity in the rat brain and spinal cord. Peptides 20, 1455-1470.

Dagerlind A, Friberg K, Bean A \& Hokfelt T (1992) Sensitive mRNA detection using unfixed tissue: Combined radioactive and non-radioactive in situ hybrid histochemistry. Histochemistry $\mathbf{9 8}$, $39-49$.

Date Y, Ueta Y, Yamashita H, Yamaguchi H, Matsukura S, Kangawa K, Sakurai T, Yanagisawa M \& Nakazato M (1999) Orexins, orexigenic hypothalamic peptides, interact with autonomic, neuroendocrine and neuroregulatory systems. Proceedings of the National Academy of Sciences USA 96, 748-753.

de Lecea L, Kilduff TS, Peyron C, Gao X-B, Foye PE, Danielson PE, Fukuhara C, Battenberg ELF, Gautvik VT, Bartlett FS, Frankel WN, van den Pol AN, Bloom FE, Gautvik KM \& Sutcliffe JG (1998) The hypocretins: Hypothalamus-specific peptides with neuroexcitatory activity. Proceedings of the National Academy of Sciences USA 95, 322-327.

Dryden S, Frankish H, Wang Q \& Williams G (1994) Neuropeptide $\mathrm{Y}$ and energy balance: One way ahead for the treatment of obesity. European Journal of Clinical Investigation 24, 293-308.

Dryden S, King P, Pickavance L, Doyle P \& Williams G (1999) Divergent effects of intracerebroventricular and peripheral leptin administration on feeding and hypothalamic neuropeptide $\mathrm{Y}$ in lean and obese ( $f a / f a$ ) Zucker rats. Clinical Science 96, 307-312.

Dryden S, King P \& Williams G (2000) Neuropeptide Y and the regulation of energy homeostasis. Behavioral and Neuropsychological Review (In the Press).

Dyer CJ, Touchette KJ, Carroll JA, Allee GL \& Matteri RL (1999) Cloning of porcine prepro-orexin cDNA and effects of an 
intramuscular injection of synthetic porcine orexin-B on feed intake in young pigs. Domestic Animal Endocrinology 16, 145-148.

Edwards CMB, Abusnana S, Sunter D, Murphy KG, Ghatei MA \& Bloom SR (1999) The effect of the orexins on food intake: Comparison with neuropeptide $\mathrm{Y}$, melanin-concentrating hormone and galanin. Journal of Endocrinology 160, R7-R12.

Egawa M, Yoshimatsu H \& Bray GA (1991) Neuropeptide Y suppresses sympathetic activity to interscapular brown adipose tissue. American Journal of Physiology 260, R328-R334.

Elias CF, Saper CB, Maratos-Flier E, Tritos NA, Lee C, Kelly J, Tatro JB, Hoffman GE, Ollmann MM, Barsh GS, Sakurai T, Yanagisawa M \& Elmquist JK (1998) Chemically defined projections linking the mediobasal hypothalamus and the lateral hypothalamic area. Journal of Comparative Neurology 402 , $442-459$.

Elmquist JK, Ahima RS, Elias CF, Flier JS \& Saper CB (1998) Leptin activates distinct projections from the dorsomedial and ventromedial hypothalamic nuclei. Proceedings of the National Academy of Sciences USA 95, 741-746.

Erickson JC, Clegg KE \& Palmiter RD (1996a) Sensitivity to leptin and susceptibility to seizures of mice lacking neuropeptide Y. Nature 381, 415-421.

Erickson JC, Hollopeter G \& Palmiter RD (1996b) Attenuation of the obesity syndrome of $o b / o b$ mice by the loss of neuropeptide Y. Science 274, 1704-1707.

Fan W, Boston BA, Kesterson RA, Hruby VJ \& Cone RD (1997) Role of melanocortinergic neurons in feeding and the agouti obesity syndrome. Nature 385, 165-168.

Flynn MC, Plata-Salaman CR \& Ffench-Mullen JM (1999) Neuropeptide Y-related compounds and feeding. Physiology and Behavior 65, 901-905.

Friedman JM \& Halaas JL (1998) Leptin and the regulation of body weight in mammals. Nature 395, 763-770.

Fuxe K, Tinner B, Caberlotto L, Bunnemann B \& Agnati LF (1997) NPY Y1 receptor like immunoreactivity exists in a subpopulation of beta-endorphin immunoreactive nerve cells in the arcuate nucleus: A double immunolabelling analysis in the rat. Neuroscience Letters 225, 49-52.

Gerald C, Walker MW, Criscione L, Gustafson EL, BatzlHartmann C, Smith KE, Vaysse P, Durkin MM, Laz TM, Linemeyer DL, Schaffhauser AO, Whiteshank S, Hofbauer KG, Taber RI, Branchek TA \& Weinshank RL (1996) A receptor subtype involved in neuropeptide Y-induced food intake. Nature 382, 168-171.

Griffond B, Risold PY, Jacquemard C, Colard C \& Fellmann D (1999) Insulin-induced hypoglycemia increases preprohypocretin (orexin) mRNA in the rat lateral hypothalamic area. Neuroscience Letters 262, 77-80.

Guan XM, Yu H, Trumbauer M, Frazier E, Van der Ploeg LH \& Chen $H$ (1998) Induction of neuropeptide $Y$ expression in dorso-medial hypothalamus of diet-induced obese mice. NeuroReport 9, 3415-3419.

Håkansson M, de Lecea L, Sutcliffe JG, Yanagisawa M \& Meister B (1999) Leptin receptor and STAT3-immunoreactivities in hypocretin/orexin neurones of the lateral hypothalamus. Journal of Neuroendocrinology 11, 653-663.

Halaas JL, Boozer C, Blair-West J, Fidhausein N, Denton DA \& Friedman JM (1997) Physiological responses to long-term peripheral and central leptin infusion in lean and obese mice. Proceedings of the National Academy of Sciences USA 94, 8878-8883.

Harrold JA, Widdowson PS \& Williams G (1999a) Altered energy balance causes selective changes in melanocortin-4 (MC4-R) but not melanocortin-3 (MC3-R) receptors in specific hypothalamic regions: Further evidence that MC4-R activation is a physiological inhibitor of feeding. Diabetes 48, 267-271.
Harrold JA, Widdowson PS \& Williams G (1999b) Changes in hypothalamic agouti-related peptide (AGRP), but not $\alpha$-MSH or pro-opiomelanocortin concentrations in dietary-obese and food-restricted rats. Biochemical and Biophysical Research Communications 258, 574-577.

Haskell-Luevano C, Chen P, Li C, Chang K, Smith MS, Cameron JL \& Cone RD (1999) Characterization of the neuroanatomical distribution of agouti-related protein immunoreactivity in the rhesus monkey and the rat. Endocrinology 140, 1408-1415.

Haynes AC, Jackson B, Overend P, Buckingham RE, Wilson S, Tadayyon M \& Arch JRS (1999) Effects of single and chronic ICV administration of the orexins on feeding in the rat. Peptides 20, 1099-1105.

Hill JO \& Peters JC (1998) Environmental contributions to the obesity epidemic. Science 280, 1371-1373.

Horvath TL, Diano S \& van den Pol AN (1999) Synaptic interaction between the hypocretin (orexin) and neuropeptide Y cells in the rodent and primate hypothalamus: A novel circuit implicated in metabolic and endocrine regulations. Journal of Neuroscience 19, 1072-1087.

Huszar D, Lynch CA, Fairchild-Huntress V, Dunmore JH, Fang Q, Berkemeier LR, Gu W, Kesterson RA, Boston BA, Cone RD, Smith FJ, Campfield LA, Burn P \& Lee R (1997) Targeted disruption of the melanocortin-4 receptor results in obesity in mice. Cell 88, 131-141.

Ida T, Nakahara K, Katayama T, Murakami N \& Nakazato M (1999) Effect of lateral cerebroventricular injection of the appetite-stimulating neuropeptide, orexin and neuropeptide Y, on the various behavioral activities of rats. Brain Research 821, $526-529$.

Inui A (1999) Neuropeptide Y feeding receptors: Are multiple subtypes involved? Trends in Pharmacological Sciences 20, 43-46.

Jegou S, Blasquez C, Delbende C, Bunel DT \& Vaundry H (1993) Regulation of $\alpha$-melanocyte-stimulating hormone release from hypothalamic neurons. Annals of the New York Academy of Sciences 680, 260-278.

Kalra SP, Dube MG, Fournier A \& Kalra PS (1991a) Structure-function analysis of stimulation of food intake by neuropeptide Y: Effect of receptor agonists. Physiology and Behavior 50, 5-9.

Kalra SP, Dube MG, Sahu A, Phelps C \& Kalra PS (1991b) Neuropeptide $\mathrm{Y}$ secretion increases in the paraventricular nucleus in association with increased appetite for food. Proceedings of the National Academy of Sciences USA 38, 10931-10935.

Kesterson RA, Huszar D, Lynch CA, Simerly RB \& Cone RD (1997) Induction of neuropeptide Y gene expression in the dorsal medial hypothalamic nucleus in two models of the agouti obesity syndrome. Molecular Endocrinology 11, 630-637.

Kiefer LL, Ittoop OR, Bunce K, Truesdale AT, Willard DH, Nichols JS, Blanchard SG, Mountjoy K, Chen WJ \& Wilkison WO (1997) Mutations in the carboxyl terminus of agouti protein decrease agouti inhibition of ligand binding to the melanocortin receptors. Biochemistry 36, 2084-2090.

Krude H, Biebermann H, Luck W, Horn R, Brabant G \& Gruters A (1998) Severe early-onset obesity, adrenal insufficiency and red hair pigmentation caused by POMC mutations in humans. Nature Genetics 19, 155-157.

Lin L, Faraco J, Li R, Kadotani H, Rogers W, Lin X, Qui X, de Jong PJ, Nishino S \& Mignot E (1999) The sleep disorder canine narcolepsy is caused by a mutation in the hypocretin (orexin) receptor 2 gene. Cell 98, 365-376.

Lu D, Willard D, Patel IR, Kadwell S, Overton L, Kost T, Luther M, Woychik RP, Wilkison WO \& Cone RD (1994) Agouti protein is an antagonist of the melanocyte stimulating-hormone receptor. Nature 371, 799-802. 
Lubkin M \& Stricker-Krongrad A (1998) Independent feeding and metabolic actions of orexins in mice. Biochemical and Biophysical Research Communications 253, 241-245.

McKibbin PE, Cotton SJ, McMillan S, Holloway B, Mayers R, McCarthy HD \& Williams G (1991) Altered neuropeptide Y concentrations in specific hypothalamic regions of obese ( $f a / f a)$ Zucker rats. Diabetes 40, 1423-1429.

Mizuno TM, Kleopoulos SP, Bergen HT, Roberts JL, Priest CA \& Mobbs CV (1998) Hypothalamic pro-opiomelanocortin mRNA is reduced by fasting in $o b / o b$ and $d b / d b$ mice, but is stimulated by leptin. Diabetes 47, 294-297.

Mondal MS, Nakazato M, Date Y, Murakami N, Yanagisawa M \& Matsukura S (1999) Widespread distribution of orexin in rat brain and its regulation upon fasting. Biochemical and Biophysical Research Communications 256, 495-499.

Moriguchi T, Sakurai T, Nambu T, Yanagisawa M \& Goto K (1999) Neurons containing orexin in the lateral hypothalamic area of the adult rat brain are activated by insulin-induced acute hypoglycemia. Neuroscience Letters 264, 101-104.

Morris BJ (1989) Neuronal localisation of neuropeptide Y gene expression in rat brain. Journal of Comparative Neurology 290, 358-368.

Mountjoy K, Mortrud M, Low M, Simerly R \& Cone R (1994) Localization of the melanocortin-4 receptor (MC4-R) in neuroendocrine and autonomic control circuits in the brain. Molecular Endocrinology 8, 1298-1308.

Nambu T, Sakurai T, Mizukami K, Hosoya Y, Yanagisawa M \& Goto K (1999) Distribution of orexin neurons in the adult rat brain. Brain Research 827, 243-260.

Ollmann MM, Wilson BD, Yang Y-K, Kerns JA, Chen Y, Gantz I \& Barsh GS (1997) Antagonism of central melanocortin receptors in vitro and in vivo by agouti-related protein. Science 278, 135-138.

Peyron C, Tighe DK, van den Pol AN, de Lecea L, Heller HC, Sutcliffe JG \& Kilduff TS (1998) Neurons containing hypocretin (orexin) project to multiple neuronal systems. Journal of Neuroscience 18, 9996-10015.

Phillips MS, Liu Q, Hammond HA, Dugan V, Hey PJ, Caskey CJ $\&$ Hess JF (1996) Leptin receptor missense mutation in the fatty Zucker rat. Nature Genetics 13, 18-19.

Pickavance L, Dryden S, Hopkins D, Bing C, Frankish H, Wang Q, Vernon RG \& Williams G (1996) Relationships between hypothalamic neuropeptide $\mathrm{Y}$ and food intake in the lactating rat. Peptides 17, 577-582.

Pu S, Jain MR, Kalra PS \& Kalra SP (1998) Orexins, a novel family of hypothalamic neuropeptides, modulate pituitary luteinizing hormone secretion in an ovarian steroid-dependent manner. Regulatory Peptides 78, 133-136.

Qu D, Ludwig DS, Gammeltoft S, Piper M, Pelleymounter MA, Cullen MJ, Mathes WF, Przypek J, Kanarek R \& Maratos-Flier $\mathrm{E}$ (1996) A role for melanin-concentrating hormone in the central regulation of feeding behaviour. Nature 380, 243-247.

Risold PY, Griffond B, Kilduff TS, Sutcliffe JG \& Fellmann D (1999) Preprohypocretin (orexin) and prolactin-like immunoreactivity are coexpressed by neurons of the rat lateral hypothalamic area. Neuroscience Letters 259, 153-156.

Roselli-Rehfuss L, Mountjoy KG, Robbins LS, Mortrud MT, Low MJ, Tatro JB, Entwistle ML, Simerly RB \& Cone RD (1993) Identification of a receptor for $\gamma$ melanotropin and other proopiomelanocortin peptides in the hypothalamus and limbic system. Proceedings of the National Academy of Sciences USA 90, 8856-8860.

Sakurai T, Amemiya A, Ishii M, Matsuzaki I, Chemelli RM, Tanaka H, Williams SC, Richardson JA, Kozlowski GP, Wilson S, Arch JRS, Buckingham RE, Haynes AC, Carr SA, Annan RS, McNulty DE, Liu W-S, Terrett JA, Elshourbagy NA, Bergsma
DJ \& Yanagisawa M (1998) Orexins and orexin receptors: A family of hypothalamic neuropeptides and $G$ protein-coupled receptors that regulate feeding behavior. Cell 192, 573-585.

Sakurai T, Moriguchi T, Furuya K, Kajiwara N, Nakamura T, Yanagisawa M \& Goto K (1999) Structure and function of human prepro-orexin gene. Journal of Biological Chemistry 274, 17771-17776.

Samson WK, Gosnell B, Chang J-K, Resch ZT \& Murphy TC (1999) Cardiovascular regulatory actions of the hypocretins in brain. Brain Research 831, 248-253.

Sanacora G, Kershaw M, Finkelstein JA \& White JD (1990) Increased hypothalamic content of preproneuropeptide $\mathrm{Y}$ messenger ribonucleic acid in genetically obese Zucker rats and its regulation by food deprivation. Endocrinology 127, 730-737.

Satoh N, Ogawa Y, Katsuura G, Tsuji T, Masuzaki H, Hiraoka J, Okazaki T, Tamaki M, Hayase M, Yoshimasa Y, Nishi S, Hosoda K \& Nakao K (1997) Pathophysiological significance of the obese gene product, leptin, in ventromedial hypothalamus (VMH)-lesioned rats: Evidence for the loss of its satiety effect in VMH-lesioned rats. Endocrinology 138, 947-954.

Schaffauser AO, Stricker-Krongrad A, Brunner L, Cumin F, Gerald C, Whitebread S, Criscione L \& Hofbauer KG (1997) Inhibition of food intake by neuropeptide $\mathrm{Y} \mathrm{Y}_{5}$ receptor subtype antisense oligodeoxynucleotides. Diabetes 46, 1792-1798.

Schioth HB, Muceniece R, Mutulis F, Bouifrouri AA, Mutule I \& Wikberg JES (1999) Further pharmacological characterisation of the selective melanocortin 4 receptor antagonist HS014: Comparison with SHU9119. Neuropeptides 33, 191-196.

Schwartz MW, Figlewicz DP, Baskin DG, Woods SC \& Porte DJ (1992) Insulin in the brain: A hormonal regulator of energy balance. Endocrine Reviews 13, 387-414.

Schwartz MW, Seeley RJ, Woods SC, Weigle DS, Campfield LA, Burn P \& Baskin DG (1997) Leptin increases hypothalamic proopiomelanocortin mRNA expression in the rostral arcuate nucleus. Diabetes 46, 2119-2123.

Seeley RJ, Yagaloff KA, Fisher SL, Burn P, Thiele TE, van Dijk G, Baskin DG \& Schwartz MW (1997) Melanocortin receptors in leptin effects. Nature 390, 349.

Shutter JR, Graham M, Kinsey AC, Scully S, Luthy R \& Stark KL (1997) Hypothalamic expression of ART, a novel gene related to agouti, is up-regulated in obese and diabetic mutant mice. Genes Development 11, 593-602.

Siegel JM (1999) Narcolepsy: A key role for hypocretins (orexins). Cell 98, 409-412.

Sindelar DK, Marsh DJ, Mystkowski PM, Palmiler R \& Schwartz W (1999) Attenuation of diabetic hyperphagia in neuropeptide $Y$ deficient mice. Diabetes 48, Suppl. 1, A26.

Smith MS (1993) Lactation alters neuropeptide-Y and proopiomelanocortin gene expression in the arcuate nucleus of the rat. Endocrinology 133, 1258-1265.

Stephens TW, Basinski M, Bristow PK, Bue-Valleskey JM, Burgett SG, Craft L, Hales J, Hoffmann J, Hsiung HM, Kriauciunas A, MacKeller W, Rosteck PR, Schoner B, Smith D, Tinsley FC, Zhang XY \& Heiman M (1995) The role of neuropeptide Y in the antiobesity actions of the obese gene product. Nature 377, 530-532.

Sweet DC, Levine AS, Billington CJ \& Kotz CM (1999) Feeding response to central orexins. Brain Research 821, 535-538.

Taheri S, Mahmoodi M, Opacka-Juffry J, Ghatei MA \& Bloom SR (1999) Distribution and quantification of immunoreactive orexin A in rat tissues. FEBS Letters 457, 157-161.

Takahashi N, Okumura T, Yamada H \& Kohgo Y (1999) Stimulation of gastric acid secretion by centrally administered orexin-A in conscious rats. Biochemical and Biophysical Research Communications 254, 623-627. 
Trivedi P, Yu H, MacNeil DJ, Van der Ploeg LHT \& Guan X-M (1998) Distribution of orexin receptor mRNA in the rat brain. FEBS Letters 438, 71-75.

van den Pol AN (1999) Hypothalamic hypocretin (orexin): Robust innervation of the spinal cord. Journal of Neuroscience 19, 3171-3182.

van den Pol AN, Gao X-B, Obrietan K, Kilduff TS \& Belousov AB (1998) Presynaptic and postsynaptic actions and modulation of neuroendocrine by a new hypothalamic peptide, hypocretin/ orexin. Journal of Neuroscience 19, 7962-7971.

Vettor R, Zarjevski N, Cusin I, Rohner-Jeanrenaud F \& Jeanrenaud B (1994) Induction and reversibility of an obesity syndrome by intracerebroventricular neuropeptide $\mathrm{Y}$ administration to normal rats. Diabetologia 37, 1202-1208.

Wang Q, Bing C, Al-Barazanji K, Mossakowaska DE, Wang X-M, McBay DL, Neville WA, Taddayon M, Pickavance L, Dryden S, Thomas MEA, McHale MT, Gloyer IS, Wilson S, Buckingham R, Arch JRS, Trayhurn P \& Williams $G$ (1997) Interactions between leptin and hypothalamic neuropeptide $\mathrm{Y}$ neurons in the control of food intake and energy homeostasis in the rat. Diabetes 46, 335-341.

Widdowson PS, Upton R, Henderson L, Buckingham R, Wilson S \& Williams G (1997) Reciprocal regional changes in brain NPY receptor density during dietary restriction and dietary-induced obesity in the rat. Brain Research 774, 1-10.

Wijker M, Wszolek ZK, Wolters ECH, Rooimans MA, Pals G, Pfeiffer RF, Lynch T, Rodnitzky RL, Wilhelmsen KC \& Arwert F (1996) Localization of the gene for rapidly progressive autosomal dominant parkinsonism and dementia with pallido- ponto-nigral degeneration to chromosome 17q21. Human Molecular Genetics 5, 151-154.

Wilding JP, Gilbey SG, Bailey CJ, Batt RA, Williams G, Ghatei MA \& Bloom SR (1993) Increased neuropeptide-Y messenger ribonucleic acid (mRNA) and decreased neurotensin mRNA in the hypothalamus of the obese $(o b / o b)$ mouse. Endocrinology 132, 1939-1944.

Wilding JP, Gilbey SG, Mannan M, Aslam N, Ghatei MA \& Bloom SR (1992) Increased neuropeptide $Y$ content in individual hypothalamic nuclei, but not neuropeptide $\mathrm{Y}$ mRNA, in diet-induced obesity in rats. Journal of Endocrinology 132, 299-304.

Wilhelmsen KC, Lynch T, Pavlou E, Higgins M \& Hygaard TG (1994) Localization of disinhibition-dementia-parkinsonismamyotrophy complex to 17q21-22. American Journal of Human Genetics 55, 1159-1165.

Woods SC, Seeley RJ, Porte D \& Schwartz MW (1998) Signals that regulate food intake and energy homeostasis. Science $\mathbf{2 8 0}$, $1378-1382$.

Yamamoto Y, Ueta Y, Date Y, Nakazato M, Hara Y, Serino R, Nomura M, Shibuya I, Matsukura S \& Yamashita H (1999) Down regulation of prepro-orexin gene expression in genetically obese mice. Molecular Brain Research 65, 14-22.

Yeo GSH, Farooqi S, Aminian S, Halsall DJ, Stanhope RG \& O'Rahilly S (1998) A frameshift mutation in MC4-R associated with dominantly inherited human obesity. Nature Genetics 20, 111-112.

Zoli M, Torri C, Ferrari R, Jansson A, Zini I, Fuxe K \& Agnati LF (1998) The emergence of the volume transmission concept. Brain Research Reviews 26, 136-147. 